\title{
Crystal structure of $\mathrm{Ba}\left(\mathrm{Mg}_{1 / 3} \mathrm{Ta}_{2 / 3}\right) \mathrm{O}_{3}$ calcinated at $1400^{\circ} \mathrm{C}$
}

\author{
JANASWAMY SRINIVAS, E D DIAS and \\ G SREENIVASA MURTHY* \\ Department of Physics. Indian Institute of Technology, Madras 600 036, India \\ MS received 2 May 1995
}

Abstract. A new phase of $\mathrm{Ba}\left(\mathrm{Mg}_{1 / 3} \mathrm{Ta}_{2 / 3}\right) \mathrm{O}_{3}$ has been obtained by calcination at $1400 \mathrm{C}$. It belongs to the cubic $P m 3 m$ with $a=4.08840$ (4) $\AA$ and the crystal structure has been found to be the ideal perovskite by the Rietveld method from powder X-ray diffraction data.

Keywords. Calcination; crystal structure; perovskite; Rietveld method.

\section{Introduction}

Materials with high dielectric constant and low dielectric loss are used as dielectric resonators at microwave frequencies. It is well known that ceramics with the general formula $\mathrm{Ba}\left(\mathrm{B}_{1 / 3}^{\prime} \mathrm{B}_{2 / 3}^{\prime \prime}\right) \mathrm{O}_{3}$, where $\mathrm{B}^{\prime}$ is divalent $\mathrm{Zn}$ or $\mathrm{Mg}$ and $\mathrm{B}^{\prime \prime}$ the pentavalent $\mathrm{Nb}$ or Ta. have low dielectric loss at microwave frequencies (Nomura et al 1982; Kawashima et al 1977, 1983). The complex perovskite oxides have an ordered phase depending upon the charge imbalance and difference in the size of $\mathrm{B}^{\prime}$ and $\mathrm{B}^{\prime \prime}$ ions (Galasso and Pyle 1963). The degree of long-range order is influenced by the preparation method and the conditions of the heat treatments (Kawashima et al 1983). $\mathrm{Ba}\left(\mathrm{Mg}_{1 / 3} \mathrm{Ta}_{2 / 3}\right) \mathrm{O}_{3}(\mathrm{BMT})$ is a low loss dielectric material with a small temperature coefficient of resonant frequency. We report here a new cubic $P m 3 m$ phase of BMT obtained on calcination at $1400^{\circ} \mathrm{C}$.

\section{Material preparation}

The starting materials $\mathrm{BaCO}_{3}\left(99 \cdot 9 \%\right.$ pure), $\mathrm{Ta}_{2} \mathrm{O}_{5}(99 \cdot 99 \%)$ and $\mathrm{MgO}(99 \cdot 95 \%)$, obtained from CERAC Inc., USA, were mixed in the correct proportions according to the equation

$$
\mathrm{BaCO}_{3}+(1 / 3) \mathrm{MgO}+(2 / 3) \mathrm{Ta}_{2} \mathrm{O}_{5} \rightarrow \mathrm{Ba}\left(\mathrm{Mg}_{1 / 3} \mathrm{Ta}_{2 / 3}\right) \mathrm{O}_{3}+\mathrm{CO}_{2} \uparrow,
$$

using a small quantity of distilled water. The mixing was done with agate balls in a teflon jar for $24 \mathrm{~h}$. The mixture was fired at $1400^{\circ} \mathrm{C}$ for $10 \mathrm{~h}$ in air. No reaction with the crucible used was noticeable.

\section{Data collection}

The powder was back-pressed into a standard aluminium holder and mounted in a Philips PW1710 diffractometer equipped with a PW1877 automatic-step scanning system. Intensity data were collected at $300 \mathrm{~K}$ at intervals of $0 \cdot 04$ over the $2 \theta$ range $20-120^{\circ}$, with a count time of $20.0 \mathrm{~s}$ at each step, employing $1 / 2^{\circ}$ divergence, $1^{\circ}$

*Author for correspondence 
scattering and $0.3 \mathrm{~mm}$ receiving slits. $\mathrm{Ni}$-filtered $\mathrm{CuK} \alpha$ radiation was used. The $\mathrm{X}$-ray tube was operated at $40 \mathrm{KV}$ and $30 \mathrm{~mA}$ with automatic dead-time corrections during the data collection.

\section{Structure refinement and discussion}

Least-squares structure refinement was carried out using the Rietveld analysis program DBWS9006-PC (Sakthivel and Young 1992). The pseudo-Voigt profile shape function was used. Twenty times the FWHM was assumed to be the range of the calculated profile. The initial values of the background parameters were determined by fitting a fifth-order polynomial to a set of carefully selected background intensities. The weight assigned to the intensity $y_{\mathrm{i}}$ at each step $\mathrm{i}$ in the pattern was $w_{\mathrm{i}}=1 / y_{\mathrm{i}}$ and the function minimized was $\Sigma_{\mathrm{i}} w_{\mathrm{i}}\left(y_{\mathrm{io}}-y_{\mathrm{ic}}\right)^{2}$, where the subscripts o and c denote the observed and calculated quantities, respectively. The scattering factors of $\mathrm{Ba}^{2+}, \mathrm{Mg}^{2+}$ and $\mathrm{Ta}^{5+}$ were taken from the program DBWS9006-PC and those of $\mathrm{O}^{2-}$ from Hovestreydt (1983).

It is known that BMT is isomorphous with $\mathrm{Sr}\left(\mathrm{Mg}_{1 / 3} \mathrm{Ta}_{2 / 3}\right) \mathrm{O}_{3}$ (ordered trigonal $P \overline{3} \mathrm{~m} 1$ ) (Galasso and Pyle 1963). The recorded data when subjected to the Rietveld refinement based on the model yielded the residual factors $\mathrm{R}-\mathrm{P}=5 \cdot 42, \mathrm{R}-\mathrm{Wp}=9.41$ and R-Bragg $=6.78 \%$ with $a=5.7816$ and $c=7.0814 \AA$. Ba and Ta atoms had negative thermal parameters. Further this structure was developing peaks of low intensity in the regions in which there was none. This lead us to suspect the starting model.

A careful analysis of the $d$-values revealed that they could be indexed on a cubic system with a lattice constant of 8.176 or $4.088 \AA$. The refinement was attempted assuming the structure to be isomorphous with $\mathrm{A}_{2}\left(\mathrm{~B}^{\prime} \mathrm{B}^{\prime \prime}\right) \mathrm{O}_{6}$ (partially ordered cubic $F m 3 m$ ) (Galasso and Darby 1962) with an initial value of $a=8.176 \AA$. It gave the residual factors $\mathrm{R}-\mathrm{P}=5.30, \mathrm{R}-\mathrm{Wp}=10.54$ and $\mathrm{R}-\mathrm{Bragg}=8.58 \%$ and positive thermal factors for all the atoms.

The structure was finally attempted in the space group $P m 3 m$ with the smaller unimolecular cubic cell. All the atoms occupy the special positions listed in table $1 . \mathrm{Mg}$ and $\mathrm{Ta}$ are at the body centre of the cube in the stoichiometric ratio. Refinement in this space group gave us the $\mathrm{R}$ factors: $\mathrm{R}-\mathrm{P}=3 \cdot 78, \mathrm{R}-\mathrm{Wp}=5 \cdot 22$ and $\mathrm{R}-\mathrm{Bragg}=3 \cdot 50 \%$. An examination of the difference plot revealed the presence of the ordered trigonal phase of BMT. The refinement was continued with the two phases. The final residual factors are given in table 1 . The observed and calculated powder diffraction profiles based on the two phases are shown in figure 1 . The weight of the cubic phase in the sample employed was calculated to be $91.4 \%$.

In $P m 3 m$ each $\mathrm{Ta} / \mathrm{Mg}$ is at the centre of six oxygen atoms which are at the corners of a regular octahedron. The distance between $\mathrm{Ta} / \mathrm{Mg}$ and $\mathrm{O}$ is 2.04420 (2) $\AA$. The $\mathrm{Ba}$ atom has twelve oxygen atoms, each at a distance $2.89050(3) \AA$, forming a cubooctahedron. This is the ideal perovskite structure, which $\mathrm{BaTiO}_{3}$ has above $120^{\circ} \mathrm{C}$.

The disordered cubic $P m 3 m$ phase is perhaps due to the calcination temperature of $1400^{\circ} \mathrm{C}$ employed. Calcination at an appropriate temperature may lead to the ordered phase $P \overline{3} \mathrm{~m} 1$. This shows that apart from the difference in the size of the B-cations, the calcination temperature has a crucial role to play in determining the ordering of BMT structure. 
Table 1. Positional and thermal parameters in $\mathrm{Pm} 3 m$ phase of BMT.

\begin{tabular}{lcccc}
\hline Atom & $x$ & $y$ & $z$ & $\mathrm{~B}_{\text {iso }}\left(\AA^{2}\right)$ \\
\hline $\mathrm{Ba}$ & 0 & 0 & 0 & $0 \cdot 23(5)$ \\
$\mathrm{Mg}$ & $1 / 2$ & $1 / 2$ & $1 / 2$ & $0 \cdot 15(5)$ \\
$\mathrm{Ta}$ & $1 / 2$ & $1 / 2$ & $1 / 2$ & $0 \cdot 15(5)$ \\
$\mathrm{O}$ & 0 & $1 / 2$ & $1 / 2$ & $0.67(13)$ \\
\hline
\end{tabular}

$$
\begin{aligned}
& a=4 \cdot 08840(4) \AA, Z=1, \mathrm{dcal}=7 \cdot 63 \mathrm{~g} / \mathrm{cm}^{3} . P m 3 m \\
& \mathrm{R}-\mathrm{P}=3.45, \mathrm{R}-\mathrm{Wp}=4 \cdot 70, \mathrm{R}-\mathrm{Bragg}=2.28 \% \\
& S=1.98, \mathrm{D}-\mathrm{W} \mathrm{D}=0.77 \\
& \mathrm{Mg} / \mathrm{Ta}-\mathrm{O}=6 \times 2 \cdot 04420(1) \AA \\
& \mathrm{Ba}-\mathrm{O}=12 \times 2 \cdot 89050(3) \AA .
\end{aligned}
$$

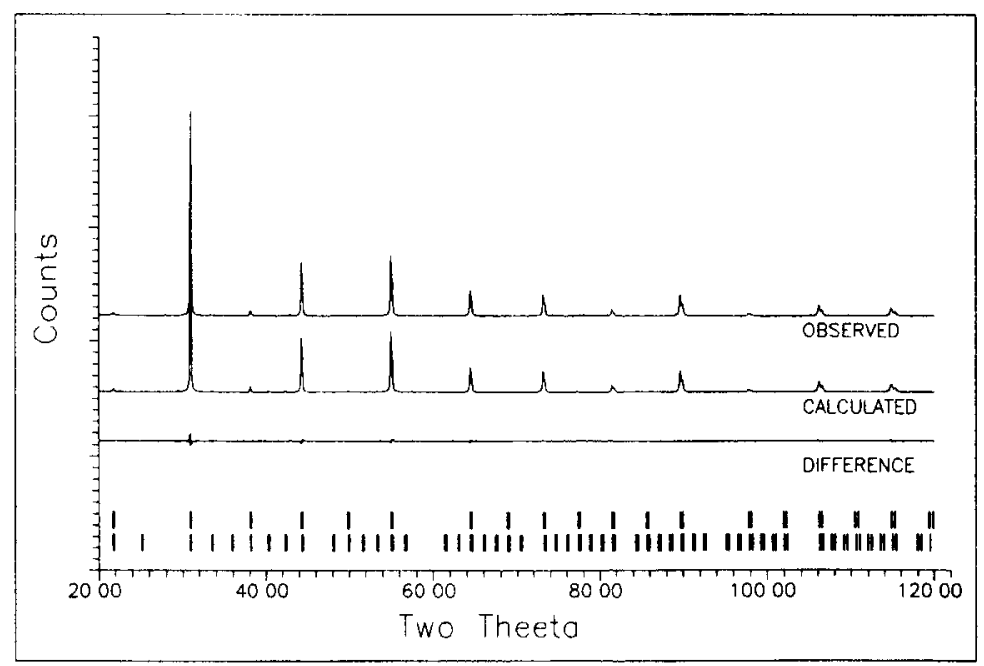

Figure 1. Observed, calculated and difference powder diffraction profiles for BMT. The two rows of short vertical lines below the pattern represent the positions of all the possible Bragg reflections of the phases, $P m 3 m$ and $P \overline{3} m 1$, respectively.

\section{Conclusion}

A new cubic $P m 3 m$ phase was established by the Rietveld profile refinement method in BMT calcinated at $1400^{\circ} \mathrm{C}$.

\section{References}

Galasso F and Darby W 1962 J. Phys. Chem. 66131

Galasso F and Pyle J 1963 Inorg. Chem. 2482

Hovestreydt E 1983 Acta Crystallogr. A39268

Kawashima S, Nishida M, Ueda I, Ouchi H and Hayakawa S 1977 Proc. Ferroelectr. Mater. Appl. 1293

Kawashima S, Nishida M, Ueda I and Ouchi H 1983 J. Am. Ceram. Soc. 66421

Nomura S, Toyama K and Kaneta K 1982 Jpn. J. Appl. Phys. 21 L624

Sakthivel A and Young R A 1992 Program DBWS-9006PC for Rietveld analysis of X-ray and neutron powder diffraction patterns 